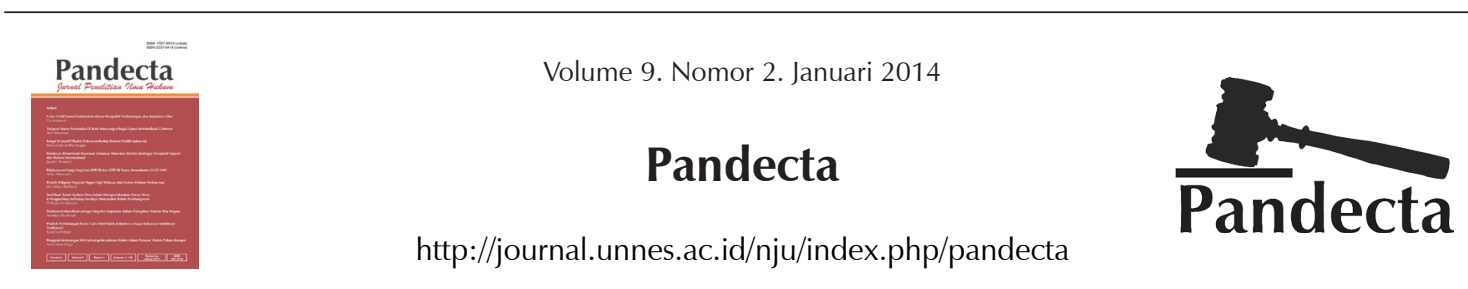

\title{
Peran Serikat Buruh Migran Indonesia dalam Melindungi Hak Tenaga Kerja Indonesia di Luar Negeri
}

\author{
Fenny Sumardiani ${ }^{\varpi}$
}

Balai Pengelola Ahli Teknologi Pertanian, Indonesia

\begin{tabular}{l} 
Info Artikel \\
\hline Sejarah Artikel: \\
Diterima Oktober \\
2014 \\
Disetujui November \\
2014 \\
Dipublikasikan De- \\
sember 2014
\end{tabular}

Keywords:

Indonesian Workers;

Trade Union;

Migrant Workers

\begin{abstract}
Abstrak
Permasalahan yang dihadapi Tenaga Kerja Indonesia baik pada fase pra penempatan, selama masa penempatan sampai dengan pasca penempatan dari waktu ke waktu perlu diperbaiki karena memang sangat luas dan membutuhkan koordinasi banyak pihak baik Pemerintah, PPTKIS, maupun organisasi yang membantu menyuarakan hak Tenaga Kerja Indonesia yang biasa disebut dengan Serikat Buruh Migran Indonesia dan Tenaga Kerja Indonesia itu sendiri. Koordinasi yang dimaksudkan terutama adalah dalam melindungi hak Tenaga Kerja Indonesia yang bermasalah. Penelitian ini bertujuan untuk menganalisis peran Serikat Buruh Migran Indonesia dalam melindungi Hak Tenaga Kerja Indonesia yang bermasalah di Kabupaten Kendal serta kendala yang dihadapi Serikat Buruh Migran dalam memperjuangkan hak-hak TKI yang bermasalah di Kabupaten Kendal serta serta upaya apa yang dilakukan untuk mengatasi kendala tersebut. Metode yang digunakan dalam penelitian ini adalah metode pendekatan yuridis sosiologis dengan metode analisa data kualitatif. Hasil penelitian ini menunjukan bahwa peran Serikat Buruh Migran Indonesia dalam menagani masalah TKI dengan memberikan pendampingan kepada tenaga kerja indonesia dan keluarganya yang mengalami masalah pada saat bertugas maupun purna tugas; memberikan pendidikan kritis; memberikan pemberdayaan ekonomi dalam peningkatan kesejahteraan bagi para anggota dan keluarganya; memberikan pelatihan bagi para tenaga kerja indonesia yang sudah kembali ke indonesia.
\end{abstract}

\begin{abstract}
The problem faced by Indonesian Manpower both the phase pre placement, during placement until after placement from time to time need to be fixed because it is very broad and requires coordination of many parties, both Governments, PPTKIS, as well as organizations that help expressing the rights of Indonesian Workers usual called the Indonesian Migrant Workers Union and Labour Indonesia itself. Coordination is intended primarily to protect the rights of Indonesian Workers are problematic. This study aims to analyze the role of Indonesian Migrant Workers Union in protecting the rights of Indonesian manpower problems in Kendal and constraints faced Migrant Workers Union in fighting for the rights workers who have problems in Kendal as well and what efforts are being made to overcome these obstacles. The method used in this study is a socio-juridical approach to qualitative data analysis method. These results indicate that the role of the Indonesian Migrant Workers Union in menagani TKI problem with providing assistance to Indonesian workers and their families who are having problems in the line of duty or full duty; provide critical education; provide economic empowerment in improving the welfare of members and their families; provide training for Indonesian workers who had returned to Indonesia.
\end{abstract}




\section{Pendahuluan}

Jamak diketahui bahwa kemiskinan menjadi faktor dominan yang menjadi pendorong bagi warga Indonesia untuk memilih bekerja ke luar negeri sebagai Tenaga Kerja Indonesia. Tetapi ternyata pilihan untuk menjadi Tenaga Kerja Indonesia tidak berbanding lurus dengan peningkatan taraf hidup dan keluarganya, karena banyak sekali permasalahan yang kemudian menimpa Tenaga Kerja Indonesia.

Aspek perlindungan hukum yang terjadi saat ini pemerintah kurang memperhatikan masyarakat yang bekerja di luar negeri. Dalam proses bertemunya dan permintaan tenaga kerja dari suatu negara ke negara lain tentu akan menjadi suatu tranformasi nilai, sehingga sering terjadi problematika dari segi sosial dan segi hukum yang dihadapi oleh tenaga kerja Indonesia. Berbagai permasalahan yang sering dihadapi oleh tenaga kerja Indonesia yang bekerja di luar negeri demikian ini terjadi pada fase prapenempatan, selama masa penempatan sampai dengan pasca penempatan. Dalam setiap fase tersebut mempunyai tiga pola yaitu tenaga kerja, pengusaha penempatan kerja serta Pemerintah selaku pembuat kebijakan. Padahal, sebagaimana tenaga kerja lainnya di dunia, Tenaga Kerja Indonesia mempunyai hak-hak yang sangat penting (ILO. 2007; Wijayanti, 2012). Salah satu hal tersebut adalah hak memperoleh jaminan perlindungan hukum sesuai dengan perundang-undangan yang berlaku atas tindakan yang dapat merendahkan harkat dan martabat para Tenaga Kerja Indonesia yang bekerja di luar negeri serta hak-hak yang ditetapkan sesuai dengan peraturan perundangundangan selama penempatan di luar negeri dan memperoleh jaminan perlindungan keselamatan dan keamanan kepulangan Tenaga Kerja Indonesia(TKI) ke tempat asal.

Nasib Serikat Buruh Migran di Indonesia semakin terpuruk, banyak serikat buruh migran tetapi mereka sendiri tidak kompak. Serikat Buruh Migran Indonesia ada banyak yang tidak mengakar keburuh itu sendiri organisasi-organisasi yang muncul dengan jumlah anggota tidak jelas. Bahkan ada organisasi buruh hanya punya kepengurusan saja tapi sama sekali tidak mempunyai anggota.

Menurut Program Pemberdayaan Buruh Migran Perempuan dan Keluarganya di Daerah asal diterbitkan oleh Yayasan Tifa dan Badan Nasional Penempatan dan Perlindungan Tenaga Kerja Indonesia, Ada beberapa contoh kasus yang terjadi dan ditangani oleh organisai pembela buruh migran di CirebonJawa Barat, bahwa DPC SBMI (Serikat Buruh Migran Indonesia) Kabupaten Cirebon telah menerima pengaduan dari Sdr. Kasir yang merupakan suami seorang Tenaga Kerja luar negeri yang beralamat di Desa Gagasari RT 05atau02 Kecamatan Gebang Kabupaten Cirebon.

TKI yang bermasalah karena mengalami penganiayaan yang dilakukan majikannya hingga mengalami sakit patah tulang belakang dan masih berbaringataulumpuh. Kemudian pihak agency PPTKIS menjanjikan akan memberikan asuransi Tenaga Kerja Indonesia, tetapi proses klaim asuransi tidak bisa diurus dengan alasan Tenaga Kerja Indonesia pura-pura sakit. Karena pihak TKI merasa dibohongi maka dari itu pihak TKI melaporkan kasus tersebut kepada pihak SBMI untuk menyelesaikan kasus yang dialami oleh TKI. Pihak SBMI melakukan pendampingan meminta pertanggungjawaban kepada pihak-pihak terkait atas Penempatan TKI dalam hal ini PPTKIS maupun pemerintah untuk memenuhi hak-haknya (klaim asuransi TKI) dan biaya penyembuhanataupengobatan bagi TKI yang mengalami masalah.

Maka dari itu Serikat Buruh Migran Indonesia sendiri adalah organisasi masa tenaga kerja Indonesia yang terdiri dari tenaga kerja Indonesia aktif, mantan tenaga kerja Indonesia, calon tenaga kerja Indonesia, dan anggota keluarganya serta masyarakat yang peduli akan isu tenaga kerja Indonesia (Asikin, 2004). Organisasi tenaga kerja Indonesia ini untuk membantu memperjuangkan hak para tenaga kerja Indonesia. Organisasi ini didirikan karena mereka mengalami sendiri permasalahan-permasalahan yang terjadi pada saat bekerja di luar negeri. Serikat buruh migran Indonesia memperjuangkan hak para tenaga kerja Indonesia yang mengalami kesulitan, kurang nya peran dari Pemerintah ini yang membuat mereka mendirikan suatu 
organisasi serikat buruh migrant Indonesia.

Berdasarkan persoalan tersebut, dua pertanyaan utama yang akan dijawab dalam paper ini adalah: 1) Bagaimana Peran Serikat Buruh Migran Indonesia dalam melindungi Hak Tenaga Kerja Indonesia yang bermasalah di Kabupaten Kendal? 2) Bagaimana Kendala yang dihadapi Serikat Buruh Migran Indonesia dalam memperjuangkan hak-hak TKI yang bermasalah di Kabupaten Kendal serta serta upaya apa yang dilakukan untuk mengatasi kendala tersebut?

\section{Metode Penelitian}

Penelitian menggunakan metode penelitian kualitatif dengan pendekatan yuridis sosiologis. Pendekatan yuridis sosiologis hukum adalah pendekatan dengan melihat sesuatu kenyataan hukum di dalam masyarakat (Afifudin \& Saebani, 2009; Amiruddin \& Asikin, 2004; Arikunto, 2002). Penelitian ini peneliti akan mengkaji Bagaimana peran Serikat Buruh Migran Indonesia dalam melindungi Hak Tenaga Kerja Indonesia yang mendapat masalah setelah purna tugas di Kabupaten Kendal, serta Bagaimana kendala yang dihadapi Serikat Buruh Migran dalam memperjuangkan hak Tenaga Kerja Indonesia yang bermasalah di Kabupaten Kendal dan Upaya apa untuk mengatasi kendala tersebut. Lokasi dalam penelitian ini dilaksanakan di Wilayah kendal, terutama di daerah yang memiliki permasalahan tentang TKI, lokasi dalam penelitian ini adalah BP3TKI, Serikat Buruh Migran Indonesia cabang Kabupaten Kendal, korban TKI yang hak-haknya tidak terpenuhi.

\section{Hasil dan Pembahasan}

\section{a. Pengertian Serikat Buruh atau Seri- kat Pekerja}

Menurut Pasal 1 ayat (17) UndangUndang No 13 Tahun 2013, pengertian dari serikat buruh atau serikat pekerja adalah "Organisasi yang dibentuk dari, oleh dan untuk pekerja atau buruh, baik diperusahaan maupun diluar perusahaan yang bersifat bebas, terbuka, mandiri, demokratis, dan bertanggung jawab guna memperjuangkan, membela serta melindungi hak dan kepen- tingan pekerja atau buruh serta meningkatkan kesejahteraan pekerja atau buruh dan keluarganya". Dalam pengertian ini, nilai-nilai demokrasi menjadi dasar yang sangat kuat bagi terbentuknya serikat buruh serta perlindungan hak-hak buruh di Indonesia (Khakim, 2003; Soepomo, 1976).

Menurut Kartasapoetra (1992:14), dalam bukunya Hukum Perburuhan di Indonesia berdasarkan Pancasila. Bahwa yang dimaksud dengan Organisasi buruh di tanah air kita adalah organisasi yang didirikan oleh dan untuk kaum buruh secara sukarela yang berbentuk Serikat Buruh dan Gabungan Serikat buruh.

Serikat buruh adalah suatu organisasi yang didirikan oleh dan untuk buruh secara sukarela, berbentuk kesatuan dan mencakup lapangan pekerjaan, serta disusun secara vertikal dari pusat sampai unit-unit kerja (basis). Sedangkan Gabungan Serikat Buruh adalah suatu organisasi buruh yang anggotaanggotanya terdiri dari serikat buruh. (Asikin:2004:51; Husni, 2003)

Pengertian Serikat buruh atau pekerja jelas dijelaskan bahwa suatu organisasi atau perkumpumpulan pekerja/buruh untuk memperjuangkan dan membela hak dari para pekerja atau buruh yang tertindas.

Adapun asas Serikat Buruh menurut menurut Pasal 2 Undang-Undang Nomor 21 Tahun 2000 tentang Serikat Pekerja atau Serikat Buruh ada dua. Pertama, serikat pekerja atau serikat buruh federasi dan konfederasi serikat pekerja atau serikat buruh menerima pancasila sebagai dasar Negara dan UndangUndang Dasar 1945 sebagai konstitusi Negara Kesatuan Republik Indonesia. Kedua, serikat pekerja atau serikat buruh federasi dan konfederasi serikat pekerja atau serikat buruh mempunyai asas yang tidak bertentangan dengan Pancasila dan Undang-Undang Dasar 1945.

Adapun pengertian Serikat Buruh Migran Indonesia adalah organisasi masa buruh migran Indonesia yang terdiri dari Tenaga Kerja Indonesia aktif, mantan Tenaga Kerja Indonesia, calon Tenaga Kerja Indonesia, dan anggota keluarganya serta masyarakat yang peduli akan isu Tenaga Kerja Indonesia. Serikat Buruh Migran Indonesia menerima 
pengaduan dari para Tenaga Kerja Indonesia yang mengalami masalah, SBMI membantu meminta pertanggung jawaban pihak-pihak terkait kepada PPTKIS maupun pemerintah melalui KBRI atau instansi lainnya.

\section{b. Peran Pemerintah dan Pelaksana Penempatan TKI Swasta terhadap Buruh Migran Indonesia/Tenaga Kerja Indonesia}

Pada Undang-Undang Nomor 39 Tahun 2004 tentang Penempatan dan Perlindungan Tenga Kerja Indonesia di Luar Negeri pada Pasal 5 ayat (1) tentang tugas, tanggung jawab dan Kewajiban Pemerintah dijelaskan bahwa penyelenggaraan penempatan dan perlindungan TKI diluar negeri dilakukan secara seimbang oleh pemerintah dan masyarakat. Agar penyelenggaraan dan penempatan dan perlindungan TKI diluar negeri tersebut dapat berhasil guna dan berdaya guna pemerintah perlu mengatur, membina, dan mengawasi pelaksanaannya. Pada Pasal 6 juga dijelaskan bahwa pemerintah bertanggung jawab untuk meningkatkan upaya perlindungan TKI diluar Negeri.

Peran Negara terhadap migrasi Indonesia sangatlah penting. Potret peran Negara sejauh ini hanya dapat dilihat dari bentuk peraturan dan perundangan yang dikeluarkan sebagai respon terhadap kebutuhan Tenaga Kerja Indonesia. Indikator atas kondisi perlindungan terhadap Tenaga Kerja Indonesia setidaknya dapat dilihat dari tiga aspek yaitu pra penempatan, penempatan dan purna penempatan. Bahwa ketiga aspek tersebut turut merefleksikan bagaimana perlindungan terhadap Tenaga Kerja Indonesia. Penempatan dan perlindungan buruh migran Indonesia adalah hal yang saling terkait satu sama lain. Tidak ada penempatan jika tidak diiringi dengan perlindungan dan perlindungan ini adalah bagian dari penempatan.

Pemerintah Indonesia harus memberikan pelatihan dan mengawasi para pejabat pemerintah supaya mereka benar-benar melaksanakan dan memberlakukan peraturanperaturan perlindungan terhadap Tenaga Kerja Indonesia. Dalam hal ini peran dari pemerintah harus lebih mengambillangkahlangkah yang serius untuk menghapus pemal- suan-pemalsuan dokumen oleh agen tenaga kerja, termasuk mengawasi dan memastikan implementasi peraturan-peraturan dengan baik oleh pejabat imigrasi dan berkoordinasi dengan negara-negara lain untuk memahami permasalahan yang dihadapi.

Bahwa pendidikan dan kualitas yang belum memadai menunjukan bahwa Pemerintah dan Pelaksana Penempatan TKI Swasta (PPTKIS) mempunyai tanggung jawab besar dalam menghadirkan kualitas yang baik untuk buruh migran Indonesia. Ketidakhadiran kualitas yang memadai menjadikan Tenaga Kerja Indonesia sulit untuk bersaing dengan Tenaga Kerja Indonesia dari Negara lainnya. Tindakan kekerasan oleh majikan yang sering terjadi pada Tenaga Kerja Indonesia merupakan integrasi dari kualitas buruh migran yang minimum pendidikan berbasis keahlian dan perlindungan hukum yang lemah.

\section{c. Serikat Buruh Migran Indonesia Ka- bupaten Kendal}

Serikat Buruh Migran Indonesia Kabupaten Kendal Provinsi Jawa Tengah didirikan pada tanggal 25-26 Mei Tahun 2013 dan dilaksanakan di Desa Plososari Kecamatan Patean Kabupaten Kendal, Peresmian pengurusan diresmikan oleh Sekjen Serikat Buruh Migran Indonesia pusat dan berlangsung secara sederhana namun penuh keakraban dan semangat kekeluargaan.

Serikat Buruh Migran Indonesia Kabupaten Kendal didirikan oleh para mantan Tenaga Kerja Indonesia yang telah kembali ke Negara asal. Kebanyakan dari para anggota adalah para TKI yang mengalami masalah pada saat mereka bekerja diluar negeri sebagai TKI. Pengalaman nyata yang dihadapi oleh para perkerja TKI, dengan adanya organisasi ini sangat terbantu sekali untuk memperjuangkan hak-hak normatif sebagai Tenaga Kerja Indonesia, karena dengan membentuk organisasi ini dapat membantu buruh migran dan keluarganya.

Bahwa Serikat Buruh Migran memperjuangkan hak para Tenaga Kerja Indonesia yang mengalami kesulitan kurangnya peran dari pemerintahan. Serikat Buruh Migran Indonesia didirikan secara bebas, terbuka, mandiri, demokratis dan bertanggung jawab 
terhadap buruh migran atau TKI untuk memperjuangkan kepentingan Buruh Migran atau TKI dan keluarganya.

\section{d. Peran Serikat Buruh Migran Indo- nesia dalam melindungi Hak Tenaga Kerja Indonesia yang bermasalah di Kabupaten Kendal}

Keberadaan organisasi Serikat Buruh Migran Indonesia sangat penting bagi para Tenaga Kerja Indonesia. Bagi Tenaga Kerja Indonesia sudah jelas bahwa adanya organisasi tersebut merupakan perantara suara buruh dalam menjelaskan hak-hak mereka terhadap pemerintah. Namun selain itu bagi Buruh Migran adanya organisasi ini sangat penting untuk memberikan perlindungan dan kesejahteraan yang adil dan wajar bagi Tenaga Kerja Indonesia.

Dalam melindungi hak-hak Tenaga Kerja Indonesia peraturan yang digunakan di Indonesia adalah Undang-Undang No 39 Tahun 2004 tentang Perlindungan dan Penempatan Tenaga Kerja ke Luar Negeri, peraturan ini memiliki kekuatan terhadap peraturan dan penempatan migrasi ke Luar Negeri dan perlindungan bagi Tenaga Kerja Indonesia. Serikat Buruh Migran Indonesia dalam melindungi hak-hak Tenaga Kerja Indonesia merujuk pada Undang-Undang No 39 Tahun 2004. Serikat Buruh Migran Indonesia Tidak hanya membantu menyuarakan hak-hak Tenaga Kerja Indonesia kepada pemerintahan tetapi organisasi ini membantu melindungi dan menyelesaikan permasalahan yang dihadapi oleh Tenaga Kerja Indonesia terhadap Perusahaan yang membantu menyalurkan tenaga Kerja ke luar negeri atau PPTKIS dan pemerintah BP3TKI sendiri.

Hasil Penelitian Responden yang dilakukan oleh Ketua Serikat Buruh Migran Indonesia cabang Kabupaten Kendal dengan saudara Novi Kurniasih, Seperti yang digambarkan dalam penelitian dibawah ini. Menurut Ketua Serikat Buruh Migran Indonesia Novi Kurniasih menjelaskan

"Peran Serikat Buruh Migran Indonesia memberikan advokasi dan bantuan hukum bagi Tenaga Kerja Indonesia dan keluarganya yang mendapatkan masalah didalam negeri maupun diluar negeri. Peran Serikat Buruh Migran Indonesia sangat jelas mereka melindungi hak-hak Tenaga Kerja Indonesia yang mengalami masalah baik diluar negeri saat Tenaga Kerja Indonesia itu bekerja disana, atau pada masa purna tugas Tenaga kerja Indonesia kembali pulang Negara asal yaitu Indonesia."

Dari wawancara tersebut dapat diketahui bahwa SBMI telah melakukan upaya perlindungan terhadap Tenaga Kerja Indonesia, berdasarkan peraturan yang ada hal tersebut memungkinkan TKI dapat dengan tenang melakukan pekerjaannya tanpa mengkhawatirkan hal-hal buruk yang dapat menimpa para Tenaga Kerja Indonesia.

Serikat Buruh Migran Indonesia secara rutin melakukan sosialisasi bekerjasama dengan pemerintah, pemberdayaan perempuan, dinas sosial, dan dinas ketenagakerjaan. Sosialisasi ini diadakan supaya para calon Tenaga Kerja Indonesia mengetahui pencegahan agar tidak terjadi suatu masalah dan memberikan sosialisasi kepada calon Tenaga Kerja Indonesia mengetahui cara Prosedur pendaftaran untuk bekerja di luar Negeri serta memberikan pelatihan-pelatihan khusus terhadap para calon Tenaga Kerja Indonesia maupun yang sudah purna Tugas.

Kegiatan-kegiatan yang telah dilakukan selain pendampingan terhadap Tenaga Kerja Indonesia yang bermasalah oleh SBMI selama ini adalah:

1. 26 Mei 2013 Rapat koordinasi dengan dewan pemimpin nasional di Jakarta dengan peserta 50 orang yang menghadiri mantan TKI.

2. 12 Juni 2013 Pelatihan ayam pertelur bersama BP3TKI dan BNP2TKI dan mantan TKI di Kabupaten Kendal.

3. 17 September 2013 Pelatihan salon dengan dinaskertrans dengan peserta 40 orang dihadari oleh mantan TKI di Kabupaten Kendal.

4. 19 Januari 2014 Pelatihan pengemasan dan pembuatan Kopi Bubuk dihadiri oleh mantan TKI di Kabupaten Kendal.

5. 25-26 Januari 2014 Pelatihan pembuatan manisan jambu dihadirin oleh mantan TKI di Kabupaten Kendal

6. 3 Juni 2014 Sosialisasi penanganan 
pekerja migran bersama BP3AKB, dinas sosial, dinas ketenagakerjaan dan Transmigrasi, polisi resort dan dihadiri 6 kabupaten Kendal, pati, jepara, grobogan, kudus dan blora serta dihadiri mantan TKI dan di laksanakan di Pati.

Peran yang dilaksanakan oleh Serikat Buruh Migran Indonesia adalah mendampingi dan memberikan perlindungan terhadap TKI yang bermasalah dan membantu menyelesaikan kasus yang dialami oleh TKI. Serta memberikan peningkatan kesejahteraan Bagi para anggota dan keluarganya, SBMI memberikan pelatihan-pelatihan bagi para TKI setelah Pulang dari luar negeri dengan adanya pelatihan salon, beternak, menjahit dan sebagainya yang dapat membantu meningkatkan kesejahteraan bagi para anggota atau keluarganya, dan dengan hasil yang mereka pelajari dalam pelatihan tersebut TKI dapat mengembangkan usahanya tanpa harus kembali bekerja diluar negeri.

Masalah yang sering dihadapi Tenaga Kerja Indonesia setelah pulang Ke Negara asal adalah penggelapan dokumen, klaim asuransi, hilangnya dokumen seperti ijazah, kartu keluarga, dan buku nikah milik Tenaga Kerja Indonesia dan masalah lainnya yang dihadapi oleh Tenaga Kerja Indonesia pada masa Purna Tugas.

Berdasarkan Undang-Undang No 21 Tahun 2000 Pasal 27 ayat (1), (2) dan (3) sudah dijelaskan bahwa peran dari Serikat Buruh Migran Indonesia ini adalah melindungi hak-hak Tenaga Kerja Indonesia yang mengalami masalah dan membantu para Tenaga Kerja Indonesia dan meningkatkan kesejahteraan anggota dan keluarganya, serta mempertanggung jawabkan kegiatan organisasi kepada anggotanya sesuai dengan anggaran dasar dan anggaran rumah tangga. Bahwa dapat dilihat Peran SBMI telah sesuai dengan Undang-Undang No 21 Tahun 2000 Pasal 27 ayat (1), (2) dan (3).

Didalam Undang-Undang No 39 Tahun 2004 Pasal 1 ayat (1) dijelaskan pengertian dari Perlindungan Buruh Migran atau Tenaga Kerja Indonesia adalah Segala upaya untuk melindungi kepentingan calon TKI/ TKI dalam mewujudkan terjaminnya peme- nuhan hak-haknya sesuai dengan peraturan perundang-undangan, baik sebelum, selama, maupun sesudah bekerja.

Berdasarkan keterangan yang disampaikan oleh Novi Kurniasih selaku ketua SBMI, kasus atau perkara yang ditangani akan diselesaikan dengan beberapa proses yang telah diatur oleh Undang-Undang, namun apabila SBMI dan Pihak dari PPTKIS tidak dapat menyelesaikan kasus tersebut secara Mediasi, maka SBMI akan mengadukan kasus tersebut kepada BP3TKI untuk menyelesaikan kasus tersebut secara tripartit yang memiliki kewenangan untuk menyelesaikan kasus permasalahan TKI. Apabila sudah cukup Bukti adanya data pengadu bisa ditindak lanjutin oleh BP3TKI, maksudnya bahwa BP3TKI yang membantu membuka data tersebut seperti PPTKIS itu berada dimana. Bahwa SBMI tidak mempunyai data base, sepanjang TKI legal maka akan terdaftar di BP3TKI.

Analisis hasil wawancara tersebut menggambarkan tentang pentingnya kerjasama yang terbangun antara serikat buruh dengan BP3TKI yang secara khusus memiliki kewenangan penuh atas tenaga kerja yang berada diluar negeri. Pemerintah memiliki kekuatan untuk menekan Negara pengguna Tenaga Kerja Indonesia agar memperkerjakan para Tenaga Kerja Indonesia sesuai dengan hak-hak asasi manusia.

Menurut Balai Pelayanan Penempatan dan Perlindungan Tenaga Kerja Indonesia (BP3TKI) Bapak Pujiono "Bahwa yang berhak melindungi dan menyelesaikan kasus yang dialami TKI adalah BP3TKI karena BP3TKI dinas dari pemerintahan". Serikat Buruh Migran Indonesia hanya membantu mendampingi TKI yang bermasalah ada atau tidaknya surat kuasa pendampingan tidak menjadi masalah buat BP3TKI untuk tetap membantu memperjuangkan hak-hak TKI yang bermasalah.

Pemerintah beranggung jawab untuk meningkatkan upaya perlindungan TKI di luar negeri. Dalam melaksanakan tugas dan tanggung jawab pemerintah mempunyai setidaknya lima kewajiban: 1) menjamin terpenuhinya hak-hak calon TKI atau TKI, baik yang bersangkutan berangkat melalui pelaksanaan penempatan TKI maupun yang berangkat 
secara mandiri; 2) mengawasi pelaksanaan penempatan calon TKI; 3) membentuk dan mengembangkan sistem informasi penempatan calon TKI di luar negeri; 4) melakukan upaya diplomatik untuk menjamin pemenuhan hak dan perlindungan TKI secara optimal di negara tujuan; dan 5) memberikan perlindungan terhadap TKI selama masa sebelumnya pemberangkatan, masa penempatan dan masa purna tugas (Bambang: 2013 : 257)

Berdasarkan hasil penelitian Bahwa perlunya SBMI bekerjasama dengan BP3T$\mathrm{KI}$, Dinas Ketenagakerjaan dan Transmigrasi dalam menyelesaikan kasus BP3TKI, karena dalam buku R. Joni Bambang S. tertulis bahwa Pemerintah bertanggung jawab untuk meningkatkan upaya perlindungan TKI diluar Negeri tidak hanya masa pemberangkatan atau penempatan saja, tetapi masa purna tugas setalah kembalinya TKI ke Tanah air. SBMI hanya membantu menyuarakan dan mendampingi TKI yang bermasalah pada saat TKI purna tugas kembali ke Indonesia dan bagi para TKI yang tidak berani melapor secara langsung terhadap pemerintah, maka SBMI akan berperan sebagai perantara menyuarakan apa yang dihadapi oleh TKI, kemudian dari pihak pemerintahan BP3TKI yang menyelesaikan masalah yang dihadapi oleh TKI. Karenanya Pemerintah juga membutuhkan kerjasama dari LSM, mahasiswa dan masyarakat dalam menyelesaikan kasus yang dihadapi oleh TKI.

Di bawah ini Tabel Peran Serikat Buruh Migran dalam Melindungi Hak Tenaga Kerja Indonesia yang bermasalah di Kabupaten Kendal:

Berdasarkan tabel diatas dapat digambarkan bahwa tren kasus TKI bermasalah dari Tahun 2011-2013 selalu meningkat, dominasi kasus yang muncul banyak dari Negara Malaysia, Hongkong, Taiwan dan Singapura. Pada Negara-negara tersebut memang mayoritas TKI ditempatkan sehingga dapat dimaklumi jika banyak perkara yang muncul dan harus diselesaikan. Berbeda dengan Negara Malaysia, Negara yang memiliki rumpun masyarakat melayu seperti Indonesia kasus yang muncul jauh lebih banyak dari Negara lainnya, ini dikarenakan salah satunya karena akses yang mudah untuk menjangkau Malaysia menyebabkan Negara ini menjadi

Tabel 1. Rekapitulasi Jumlah Kasus TKI Bermasalah yang ditangani SBMI Kendal JanuariDesember 2011-2013

\begin{tabular}{|c|c|c|c|c|}
\hline Tahun & Negara & Jumalah TKI & $\begin{array}{c}\text { Selesai } \\
\text { Persentase }\end{array}$ & $\begin{array}{c}\text { Belum Selesai } \\
\text { Persentase }\end{array}$ \\
\hline \multirow{5}{*}{2011} & Malaysia & 23 & $10(43 \%)$ & $13(56 \%)$ \\
\hline & Hongkong & 5 & $3(60 \%)$ & $2(40 \%)$ \\
\hline & Taiwan & 13 & $8(61 \%)$ & $5(38 \%)$ \\
\hline & Singapura & 18 & $11(61 \%)$ & 7 (38\%) \\
\hline & Arab Saudi & 8 & $3(37 \%)$ & $5(62 \%)$ \\
\hline \multicolumn{2}{|c|}{ Jumlah } & 67 & $35(52 \%)$ & $32(47 \%)$ \\
\hline \multirow{4}{*}{2012} & Malaysia & 21 & $10(47 \%)$ & $11(52 \%)$ \\
\hline & Hongkong & 8 & $5(62 \%)$ & $3(37 \%)$ \\
\hline & Taiwan & 9 & $5(55 \%)$ & $4(44 \%)$ \\
\hline & Singapura & 14 & $7(50 \%)$ & $7(50 \%)$ \\
\hline \multicolumn{2}{|c|}{ Jumlah } & 52 & $27(51 \%)$ & $25(48 \%)$ \\
\hline \multirow{4}{*}{2013} & Malaysia & 35 & $21(60 \%)$ & $14(40 \%)$ \\
\hline & Hongkong & 21 & $15(71 \%)$ & $6(28 \%)$ \\
\hline & Taiwan & 22 & 15 (68\%) & 7 (31\%) \\
\hline & Singapura & 30 & $20(66 \%)$ & $10(33 \%)$ \\
\hline \multicolumn{2}{|c|}{ Jumlah } & 108 & $71(65 \%)$ & 37 (34\%) \\
\hline
\end{tabular}

Sumber: Data Rekapitulasi Penanganan TKI Bermasalah SBMI Kendal Januari-Desember 2011 2013 
pilihan utama para calon TKI untuk bekerja diluar negeri, sangat disayangkan akses tersebut juga tidak hanya memudahkan TKI yang legal saja, namun TKI yang illegal pun begitu mudah menjangkau Malaysia.

Sementara berdasarkan tabel diatas menggambarkan perkara yang diselesaikan oleh SBMI di tiap Tahunnya juga selalu meningkat. Ini menunjukan keberhasilan SBMI dalam mendampingi para TKI bermasalah cukup berjalan lancar. Tidak hanya karena akses jaringan yang sudah cukup luas di Negara tempat TKI berada, namun kerjasama antara SBMI dengan BP3TKI dan pemerintah tempat TKI bekerja berjalan selaras dan saling menguntungkan, itulah faktor pendukung suksesnya penanganan TKI bermasalah oleh SBMI.

\section{d. Permasalahan Yang Dihadapi Oleh TKI}

Apa yang tertulis pada proses penanganan TKI disesuaikan dengan tiap kasus atau permasalahan yang dihadapi oleh TKI ditempat mereka bekerja. Pada dasarnya TKI yang ada diluar negeri tidak semuanya merupakan TKI yang legal sementara permasalahan yang dihadapi cenderung sama, kekerasan, penganiayaan, hak yang tidak diberikan, namun permasalahan yang sama tersebut tentunya tidak dapat dihadapi dengan solusi yang sama pula mengingat status tiap TKI berbeda ada yang berstatus legal dan illegal.

Untuk mendalami permasalahan tersebut pada penelitian ini telah dilakukan wawancara secara langsung kepada 3 informan yang merupakan mantan Tenaga Kerja Indonesia diluar negeri, diantara mereka ada yang berstatus legal dan illegal.

\section{TKI Siami}

Hasil penelitian informan mantan TKI yang bernama saudara Siami, alasan saudara siami berangkat TKI dikarenakan tingkat perekonomian yang kurang dari cukup, saudara siami berangkat menjadi TKI umur 18 Tahun, 3 kali jangka waktu 8 Tahun, pertama kali mendaftar TKI secara illegal, kedua kalinya mendaftar secara legal. Sebelum keberangkatan menjadi TKI mencari sendiri pelatihan seperti mencuci pakaian, memasak dan menyetrika pakaian, pelatihan dilakukan selama setengah bulan sampai dengan pemberangkatan ke luar negeri. Pada saat di luar negeri saudara siami pernah mendapatkan perlakuan kasar dari majikan misalnya pada saat menyetrika pakaian tidak licin saudara siami mendapat perlakuan kasar ditendang oleh majikannya. Saudara siami tidak berani melapor kepada pihak berwajib karena dia diancam oleh majikan. Saudara siami mengadukan tuntutan hak nya kepada SBMI mengenai gaji selama 2 Tahun dengan besaran tiap bulannya Rp.350.000,- (tiga ratus lima puluh ribu rupiah) maka total gaji selama 2 Tahun yang belum dibayarkan sebesar Rp.8.400.000,- (delapan juta empat ratus ribu rupiah) dan saudara Siami menuntut haknya yang selama ini belum diberikan, namun sampai sekarang gaji tersebut belum diserahkan, selain gaji hak-haknya yang diminta kemudian dokumen-dokumennya seperti ijazah, buku nikah dan kartu keluarga. TKI mengadukan ke SBMI dan sampai sekarang kasus tersebut belum diselesaikan.

Menurut Saudara Siami Peran SBMI sangat membantu penanganan kasus tersebut, selain dalam penanganan kasus itu SBMI juga sangat membantu saudara siami seperti memberikan pelatihan untuk mengembangkan potensi para TKI diantaranya beternak, menjahit dan sebagainya.

\section{TKI Nurlaela}

Kemudian informan selanjutnya mantan TKI yang bernama Nurlaela, alasan berangkat bekerja ke luar negeri karena perekonomian yang kurang, Nurlaela bekerja diluar negeri tidak lama dia mulai berangkat bekerja keluar negeri pada umur 28 Tahun, saudara nurlaela telah dibohongi oleh agen, karena paspor palsu yang diberikan oleh agen. Saudara Nurlaela mengatakan "bahwa saya sendiri tidak pernah melakukan pelatihan sebelum berangkat keluar negeri, saya pernah mendapatkan perlakuan kasar dari majikan seperti ditampar dan tidak diberi makan".

Nurlaela mengatakan "bahwa saya ingin menuntut hak-hak saya, namun saya tidak tahu harus mengadu kesiapa, karena 
saya sendiri mendaftar menjadi TKI secara illegal". Dia mengadu ke SBMI setelah kembali ke Indonesia, Nurlaela menemui SBMI karena dia berharap SBMI dapat membantu menangani kasus yang pernah dialami saat menjadi TKI, tetapi SBMI sudah mencoba membantu mengadu kepada BP3TKI tetapi BP3TKI sendiri tidak bisa membantu karena TKI Nurlaela mendaftar secara illegal, SBMI memberi penjelasan kepada TKI yang mendapat masalah tentang kasus yang dialami.

\section{TKI Saidah Alanisa}

Hasil wawancara lainnya menurut mantan TKI saudara Saidah Alanisa, alasan bekerja keluar negeri karena tingkat perekonomian keluarga yang rendah, berangkat keluar negeri pada usia 27 Tahun selama 2 Tahun mendaftar keluar negeri melalui PPTKIS. Sebelum keberangkatan keluar negeri, Saidah mengikuti pelatihan misalnya merawat orang tua, menjadi pembantu, dsb. Pelatihan tersebut dilakukan setiap hari dari senin sampai sabtu. Selama menjadi TKI diluar negeri Saidah tidak pernah mendapatkan perlakuan kasar. Namun Saidah saat masih menjadi TKI di luar negeri pernah menuntut hak nya seperti asuransi lalu TKI Saidah meminta bantuan kepada SBMI dan memberikan berkas-berkasnya untuk menyelesaikan supaya kasus asuransi itu dapat selesai sesuai tuntutannya, SBMI sangat membantu sekali dalam memberikan bantuan berupa pendampingan menyelesaikan kasus asuransi.

Dari ketiga Informan diatas Tenaga Kerja Indonesia ada yang mendaftar bekerja melalui jalur resmi (legal) ada juga yang mendaftar melalui jalur tidak resmi (illegal). Bahwa ketiga Informan diatas berangkat bekerja menjadi TKI dengan pendidikan yang kurang dan informasi yang didapat kurang jelas, tidak adanya sosialisasi terlebih dahulu dari pihak pemerintah atau agen penyalur TKI yang disebut PPTKIS. Karena pendidikan yang kurang serta informasi yang didapat saat pendaftaran untuk bekerja menjadi TKI ke Luar Negeri sseringnya terjadi Permasalahan yang dihadapi oleh ke 3 (tiga) Informan diatas bahwa Tenaga Kerja Indonesia mengalami masalah dengan pihak PPTKIS nya sendiri atau dengan majikannya. Masalah yang sering dihadapi oleh Tenaga Kerja Indonesia adalah mengalami perbuatan yang tidak menyenangkan dari majikan (perlakuan kasar dan majikan terlalu ketat), mengalami masalah dengan pihak PPTKIS karena tidak diberi upah dan ada juga yang di bohongi oleh agen atau pihak PPTKIS karena dokumen-dokumen palsu karena telah mendaftar secara illegal kemudian dipulangkan ke Indonesia, ada juga yang menuntut hak nya karena kasus asuransi.

Pada Undang-Undang No 39 Tahun 2004 tentang Penempatan Perlindungan Tenaga Kerja Indonesia ke Luar Negeri pada Pasal 8 di jelaskan bahwa setiap calon TKI mempunyai hak dan kesempatan yang sama untuk: a) bekerja di luar negeri; memperoleh informasi yang benar mengenai pasar kerja keluar negeri dan prosedur penempatan TKI di luar negeri; c) memperoleh pelayanan dan perlakuan yang sama dalam penempatan di luar negeri; d) memperoleh kebebasan menganut agama dan keyakinan serta kesempatan untuk menjalankan ibadah sesuai dengan agama dan keyakinan yang dianutnya; e) memperoleh upah sesuai dengan standar upah yang berlaku di Negara tujuan; f) memperoleh hak, kesempatan dan perlakuan yang sama yang diperoleh tenaga kerja asing lainnya sesuai dengan peraturan perundangundangan di Negara tujuan; g) memperoleh jaminan perlindungan hukum sesuai dengan peraturan perundang-undangan atas tindakan yang dapat merendahkan harkat dan martabatnya sesuai dengan peraturan perundang-undangan selama penempatan di luar negeri; h) memperoleh jaminan perlindungan keselamatan dan keamanan kepulangan TKI ke tempat asal; i) memperoleh naskah perjanjian kerja yang asli.

Berdasarkan Peraturan Undang-Undangan No 39 Tahun 2004 Pasal 8 diatas dijelaskan bahwa calon TKI mempunyai hak dan kesempatan yang sama belum sesuai dengan ke 3 (tiga) TKI diatas, bahwa hasil wawancara dengan informan mantan TKI mendapatkan masalah karena kurangnya informasi dan prosedur penempatan TKI ke luar negeri, tidak diberi upah sesuai perjanjian dengan pihak PPTKIS.

Pada Pasal 42 Undang-Undang No 
39 Tahun 2004 dijelaskan tentang pendidikan dan pelatihan kerja. Pertama, calon TKI berhak mendapat pendidikan dan pelatihan kerja sesuai dengan pekerjaan yang akan dilakukan. Kedua, pendidikan dan pelatihan kerja bagi calon TKI dimaksudkan untuk membekali, menempatkan dan mengembangkan kompetensi kerja calon TKI, memberi pengetahuan dan pemahaman tentang situasi, kondisi, adat istiadat, budaya, agama dan resiko bekerja di luar negeri, membekali kemampuan berkomunikasi dalam bahasa negara tujuan, dan memberi pengetahuan dan pemahaman tentang hak dan kewajiban calon TKI/TKI.

Dengan adanya Pasal 42 UndangUndang No 39 Tahun 2004 tentang pendidikan dan pelatihan kerja sudah jelas apabila tidak ingin mendapatkan masalah pada saat TKI bekerja di luar negeri sebelum keberangkatan TKI diwajibkan untuk mendapatkan pendidikan dan pelatihan kerja dari pihak pemerintah maupun PPTKIS sendiri. Dengan diberikan pendidikan dan pelatihan kerja Agar mengurangi permasalahan seperti TKI mengalami perbuatan yang tidak menyenangkan dari majikan (perlakuan kasar dari majikan).

Terhadap beberapa permasalahan yang dihadapi oleh TKI diatas dalam hal ini pemerintah sudah memberikan perlindungan terhadap TKI yang mengalami kekerasan atau permasalahan dengan pihak PPTKIS nya sendiri, sampai saat ini pemerintah telah melakukan bantuan ataupun tindakan berdasarkan laporan TKI yang bersangkutan ataupun keluarga yang kemudian menindak lanjuti laporan tersebut sehingga perselisihan dapat diselesaikan. Namun ada juga TKI yang tidak berani menyampaikan langung masalahnya kepada PPTKIS ataupun melapor kepada pemerintah dalam hal ini BP3TKI, dengan adanya organisasi Serikat Buruh Migran Indonesia TKI dapat menyuarakan masalah yang dihadapinya. SBMI membantu mendampingi TKI dalam menyelesaikan kasus dengan PPTKIS. Dibawah ini bagan alur penyelesaian yang ditangani oleh Serikat Buruh Migran Indonesia:

Bagan diatas adalah merupakan Alur Penyelesaian yang ditangani SBMI sendiri

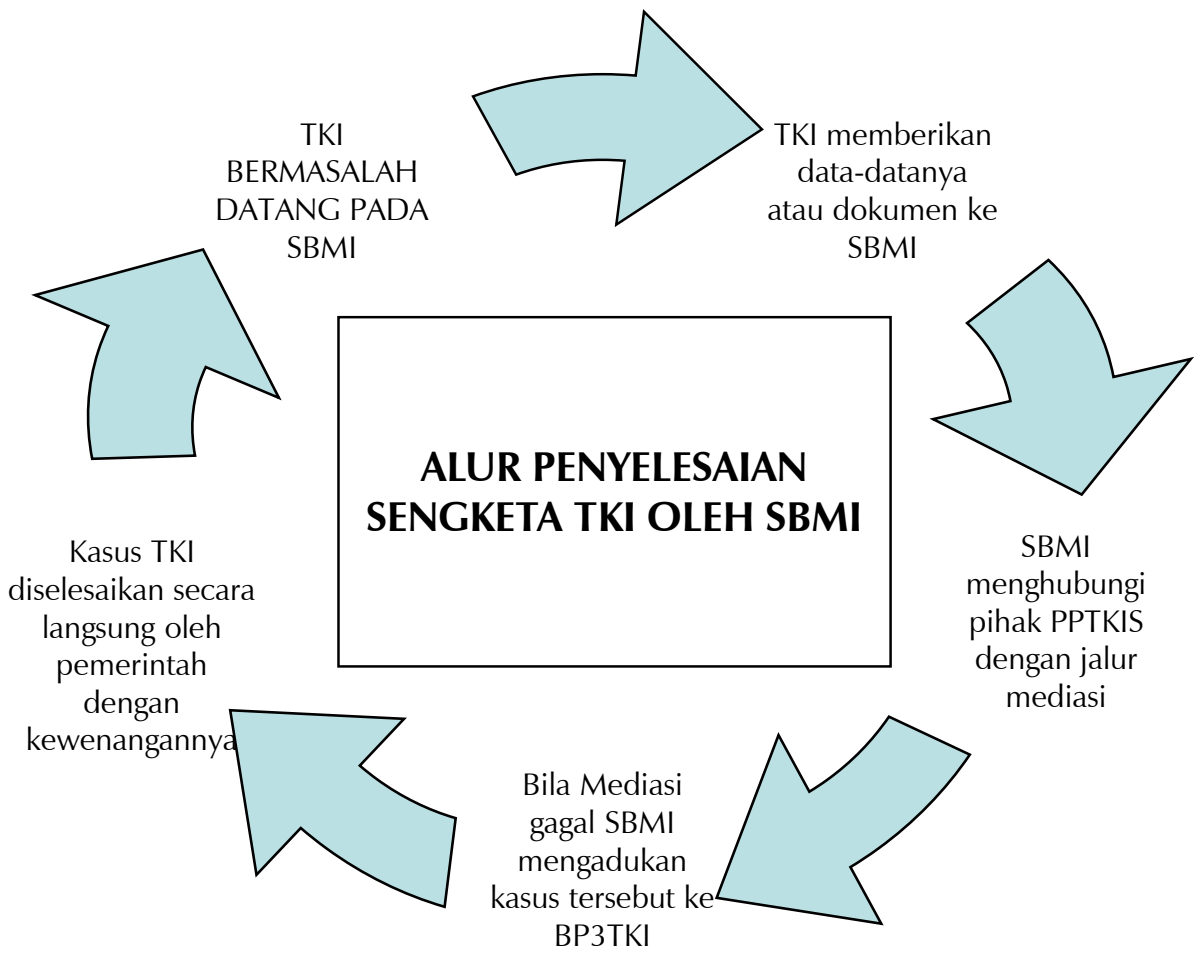

Sumber : Data yang diolah dari SBMI Cabang Kabupaten Kendal

Bagan 1. Alur Penyelesaian yang ditangani oleh Serikat Buruh Migran Indonesia 
yaitu diawali dengan TKI yang bermasalah datang sendiri ke DPC SBMI, dan menceritakan kasus yang dialami oleh TKI, menurut hasil penelitian dari Responden kasus yang lebih sering diadukan adalah permasalahan setelah masa purna tugas dengan pihak PPTKIS nya sendiri. Kemudian TKI memberikan data-datanya atau dokumen fotokopinya ke SBMI, lalu SBMI menghubungi pihak PPTKIS dengan jalur mediasi apabila PPTKIS tidak bisa diselesaikan secara mediasi lalu SBMI mengadukan kasus tersebut ke BP3TKI dan memberikan berkas-berkas tersebut ke BP3TKI yang lebih berhak menangani kasus tersebut. SBMI dalam mendampingi kasus TKI tersebut sampai selesai. Kasus yang ditangani SBMI tidak selamanya selesai secara cepat, kadang selesai selama 6 bulan atau lebih dari 3 Tahun.

Dalam melakukan kegiatan atau pendampingan menurut Ketua Serikat Buruh Migran Indonesia Novi Kurniasih "SBMI tidak pernah menarik biaya kepada setiap anggota atau TKI yang mengadukan kasusnya, menggunakan biaya pribadi atau para mantan TKI menyisihkan uangnya dana transportasi setelah melakukan kegiatan sebanyak Rp 200.000,- (dua ratus ribu rupiah) dari hasil pelatihan untuk mengembangkan usaha dari dana tersebut yang dilakukan oleh para anggota SBMI perbulannya.

Dalam menyelesaikan kasus TKI bermasalah yang dibantu oleh SBMI tidak semuanya selesai secara cepat. Menurut Novi Kurniasih mengatakan "Bahwa SBMI telah mengadukan ke BP3TKI dan memanggil pihak PPTKIS nya tetapi hingga saat ini kasusnya belum diselesaikan juga oleh BP3TKI". Maka yang mempunyai kewenangan lebih dalam menyelesaikan kasus TKI yang bermasalah adalah pemerintah.

Menurut BP3TKI Bapak pujiono "bahwa BP3TKI hanya bisa membantu membuka database para TKI serta tempat PPTKIS itu dimana sepanjang TKI tersebut mendaftar secara legal dan pihak PPTKIS juga terdaftar secara legal di BP3TKI baru BP3TKI bisa membantu menyelesaikan masalah yang dihadapi oleh TKI dengan pihak PPTKIS".

Pertentangan yang digambarkan oleh kedua responden menunjukan bahwa se- benarnya terdapat system penanganan yang kurang terkoordinasi antara SBMI, BP3TKI, serta PPTKIS. Hal tersebut yang menyulitkan penyelesaian permasalahan TKI yang dihadapi selama ini. Pemerintah perlu secara tegas mengatur alur penyelesaian yang jelas sehingga tidak berbelit-belit, apalagi ini menyangkut kedaulatan Negara di mata dunia karena TKI merupakan duta Indonesia di Negara asing, ketika TKI mudah diperlakukan buruk bisa jadi Negara lain berpandangan bahwa Indonesia dapat diperlakukan buruk.

Terbentuknya SBMI merupakan organisasi yang berkesinambung dan permanen dibentuk secara sukarela dari, oleh dan untuk Tenaga Kerja Indonesia, Peran dari SBMI ada tiga, yaitu memberikan Pengaduan dan Pendampingan kasus, memberikan pendidikan kritis, dan memberikan Pemberdayaan Ekonomi dalam peningkatan kesejahteraan bagi para anggota dan keluarganya.

Pertama, SBMI menerima pengaduan kasus dan pendampingan kepada TKI dan keluarganya yang mengalami masalah, pada saat purna tugas. Dari pengaduan yang masuk SBMI disampaikan kepada pihak yang bertanggung jawab dalam hal perlindungan TKI baik pemerintahan ataupun swasta. Karena pada dasarnya sebagai individu TKI tidak akan mampu melindungi dan memperjuangkan kepentingan dan hak-haknya, kebebasan berserikat dan berorganisasi, perlindungan akan diskriminasi, mendapatkan kesamaan kesepakatan akan pendidikan dan pelatihan. Bahwa SBMI mendampingi memberikan perlindungan terhadap TKI yang bermasalah dan membantu menyelesaikan kasus yang dialami oleh para TKI. SBMI hanya mendampingi TKI yang bermasalah, yang berkewajiban menyelesaikan kasus yang dihadapi oleh TKI adalah BP3TKI sebagai pemerintahan yang berhak melindungi dan menyelesaikan kasus yang dihadapi. SBMI sebagai sarana menyampaikan hak-hak TKI yang mengalami masalah.

Kedua, dalam melakukan kerja-kerja organisasi, SBMI melakukan kaderisasi pelatihan-pelatihan yang membangun kesadaran Tenaga Kerja Indonesia untuk mendapatkan segala hak-haknya seperti training paralegal tentang advokasi dan hukum, community 
organizer tentang organisasi dan kepemimpinan serta membuat panduan praktis yang mudah diaplikasikan oleh TKI dan keluarganya.

Ketiga, memberikan Pemberdayaan Ekonomi dalam peningkatan kesejahteraan bagi para anggota dan keluarganya. SBMI tidak hanya memberikan perlindungan terhadap hak-hak TKI yang bermasalah tetapi organisasi ini memberikan pelatihan bagi para TKI yang sudah kembali ke Indonesia supaya TKI setelah pulang dari luar negeri mereka lebih membantu keuangan keluarganya dengan adanya pelatihan salon, beternak, menjahit dan sebagainya dapat membantu meningkatkan kesejahteraan bagi para anggota atau keluarganya, dengan hasil yang mereka pelajari dalam pelatihan mereka dapat mengembangkan usahanya tanpa harus kembali bekerja keluar negeri.

Berdasarkan hasil penelitian tentang Peran Serikat Buruh Migran Indonesia Hak dan Kewajiban Serikat Buruh Migran Indonesia jika dilihat dari Pasal 25, Pasal 26 dan Pasal 27 Undang-Undang No 21 Tahun 2001 dengan kenyataan dilapangan sudah sesuai, karena hak dan kewajiban dari Serikat Buruh Migran Indonesia jika dilihat dari Undang-Undang tersebut bahwa melindungi dan membela anggota dari pelanggaran hakhak dan memperjuangkan kepentingan, serta memperjuangkan peningkatan kesejahteraan anggota dan keluarganya.

\section{e. Kendala yang dihadapi Serikat Bu- ruh Migran dalam memperjuangkan hak-hak TKI yang bermasalah di Ka- bupaten Kendal serta serta upaya apa yang dilakukan untuk mengatasi ken- dala tersebut.}

Serikat Buruh Migran Indonesia dalam menangani dan memperjuangkan hak-hak Buruh migran Indonesia/TKI yang bermasalah sebagian telah berjalan sesuai dengan ketentuan yang berlaku, namun demikian ada beberapa hal yang masih menjadi kendala. Kendala yang muncul tidak hanya dari anggotanya sendiri tetapi dari instansi pemerintah dalam membantu menangani kasus TKI yang bermasalah.

Pada Tabel 2 dapat dilihat prosentase pada Tahun 2011 masalah yang belum diselesaikan oleh SBMI sebanyak $47 \%$, pada Tahun 2012 masalah yang belum diselesaikan olehh Serikat Buruh Migran Indonesia sebanyak 48 \%, sedangkan pada Tahun 2013 masalah yang ditangani Serikat Buruh Migran Indonesia mengalami kenaikan kembali sebanyak 34 \%, Masalah yang didampingi Serikat Buruh Migran Indonesia bahwa kendala yang dihadapi oleh SBMI perTahunnya sama saja permasalahan yang dihadapi dengan pihak PPTKIS nya sendiri yang susah ditemui dan dengan pihak pemerintah dalam hal ini BP3TKI.

Berdasarkan tabel 2, pada Tahun 20112012 permasalahan yang mendominasi berdasarkan laporan yang datang ke SBMI adalah gaji yang tidak dibayarkan, pemutusan hubungan kerja (PHK) secara sepihak, dan hak asuransi kerja yang tidak diberikan pada TKI. Sementara di Tahun 2013 selain pembayaran gaji yang bermasalah, terlihat juga peningkatan jumlah permasalahan penganiayaan kepada TKI.

Dalam tabel tersebut dijelaskan penyebab kasus yang ditangani oleh SBMI Kabupaten Kendal dari Tahun 2011-2013 sudah jelas TKI yang mengalami masalah terbanyak di Negara Malaysia. Penyebab Kasus yang di bantu oleh SBMI sendiri sampai dengan selesai adalah kasus tidak digaji, dipulangkan/ PHK, bantuan Hukum serta klaim asuransi. Jumlah Kasus yang belum selesai pada tabel diatas di karenakan dari pihak TKI ada yang mendaftar secara illegal dan pihak PPTKIS yang tidak terdaftar di BP3TKI maka dari itu BP3TKI sulit untuk menyelesaikan masalah yang dihadapi oleh para TKI. Sedangkan jumlah kasus yang selesai ditangani SBMI karena Pihak PPTKIS dapat diselesaikan secara mediasi, dan data tersebut terdaftar di BP3TKI.

Dari hasil rekapitulasi diatas jumlah kasus yang didampingi SBMI tidak semuanya dapat diselesaikan oleh SBMI, ada yang di selesaikan ada juga yang belum diselesaikan, menurut Ketua SBMI Novi Kurniasih kendala yang muncul pada kasus TKI yang belum diselesaikan penyebabnya adalah karena "berkas yang telah dimasukan pada PPTKIS dalam waktu yang cukup lama namun tidak pernah ada perkembangan penyelesaian masalah 
Tabel 2. Rekapitulasi Jumlah Penyebab Kasus TKI Bermasalah yang ditangani SBMI Kendal periode Januari-Desember 2011-2013

\begin{tabular}{|c|c|c|c|c|c|c|c|}
\hline \multirow[b]{2}{*}{ Tahun } & \multirow[b]{2}{*}{ Kasus } & \multicolumn{6}{|c|}{ Negara } \\
\hline & & Malaysia & Hongkong & Taiwan & Singapura & $\begin{array}{l}\text { Arab } \\
\text { Saudi }\end{array}$ & Korea \\
\hline \multirow{9}{*}{2011} & Meninggal & 0 & 0 & 0 & 0 & 0 & 0 \\
\hline & Tidak digaji & 7 & 0 & 7 & 5 & 2 & 0 \\
\hline & Sakit & 0 & 0 & 2 & 0 & 0 & 0 \\
\hline & PHK & 6 & 2 & 3 & 3 & 4 & 0 \\
\hline & Bantuan Hukum & 3 & 1 & 0 & 7 & 2 & 1 \\
\hline & Melarikan Diri & 2 & 0 & 0 & 2 & 0 & 0 \\
\hline & Putus Komunikasi & 0 & 0 & 0 & 0 & 0 & 0 \\
\hline & Klaim Asuransi & 5 & 1 & 1 & 1 & 0 & 0 \\
\hline & Penganiayaan & 0 & 1 & 0 & 0 & 0 & 0 \\
\hline \multicolumn{2}{|c|}{ Jumlah } & 23 & 5 & 13 & 18 & 8 & 1 \\
\hline \multirow{9}{*}{2012} & Meninggal & 1 & 0 & 4 & 0 & 0 & 0 \\
\hline & Tidak digaji & 4 & 1 & 1 & 1 & 0 & 0 \\
\hline & Sakit & 0 & 0 & 1 & 2 & 0 & 0 \\
\hline & PHK & 6 & 5 & 0 & 4 & 0 & 0 \\
\hline & Bantuan Hukum & 4 & 1 & 3 & 5 & 0 & 0 \\
\hline & Melarikan Diri & 0 & 0 & 0 & 0 & 0 & 0 \\
\hline & Putus Komunikasi & 1 & 0 & 0 & 1 & 0 & 0 \\
\hline & Klaim Asuransi & 4 & 0 & 0 & 1 & 0 & 0 \\
\hline & Penganiayaan & 1 & 0 & 0 & 0 & 0 & 0 \\
\hline \multicolumn{2}{|c|}{ Jumlah } & 21 & 7 & 9 & 14 & 0 & 0 \\
\hline \multirow{9}{*}{2013} & Meninggal & 0 & 2 & 0 & 5 & 0 & 0 \\
\hline & Tidak Digaji & 12 & 6 & 0 & 4 & 0 & 0 \\
\hline & Sakit & 0 & 0 & 0 & 0 & 0 & 0 \\
\hline & PHK & 5 & 0 & 8 & 9 & 0 & 0 \\
\hline & Bantuan Hukum & 7 & 7 & 6 & 7 & 0 & 0 \\
\hline & Melarikan Diri & 1 & 0 & 0 & 0 & 0 & 0 \\
\hline & Putus Komunikasi & 2 & 0 & 2 & 1 & 0 & 0 \\
\hline & Klaim Asuransi & 4 & 6 & 6 & 4 & 0 & 0 \\
\hline & Penganiayaan & 4 & 0 & 0 & 0 & 0 & 0 \\
\hline Jumlah & & 35 & 21 & 22 & 30 & 0 & 0 \\
\hline
\end{tabular}

Sumber: Data Rekapitulasi Penanganan TKI Bermasalah SBMI Kendal Januari-Desember 2011-2013

TKI tersebut dari PPTKIS, pada dasarnya permasalahan oprasional sebenarnya cukup andil dalam tertundanya penyelesaian perkara dan juga kurangnya respon dari pemerintah".

Kendala lain yang dialami SBMI pada saat mendampingi TKI yang bermasalah dan menyelesaikan kasusnya di BP3TKI, menurut Ketua SBMI saudara Novi Kurniasih bahwa kendalanya adalah:

"Saya berharap apabila ada kasus yang muncul di beberapa daerah, BP3TKI sebagai kepanjangan tangan pemerintah dan berada di tingkat Provinsi dapat mengambil peran lebih banyak, misalnya ada kasus dari kota tegal yang ingin menyelesaikan kasusnya beberapa minggu di Semarang terkadang mereka kesulitan mendapatkan penginapan sementara yang layak, seharusnya BP3TKI dapat memberikan tempat 
penampungan sementara untuk TKI yang mengalami masalah, kasus tersebut kan tidak dapat diselesaikan secara cepat, pagi menyerahkan berkas ke BP3TKI dan sampai menunggu kasus tersebut terselesaikan, seharusnya BP3TKI memberikan kenyamanan kepada TKI yang bermasalah".

Dari kendala yang dialami konsep yang diberikan SBMI menurut Novi Kurniasih "saya pernah bilang ke kepala BP3TKI bahwa saya ingin membantu menyiapkan rumah, tetapi BP3TKI yang membantu mengisi alat-alat operasional kita membuat semacam pusat penampungan TKI Jawa Tengah yang sedang menghadapi permasalahan, apabila ada TKI yang mengalami kasus bisa tinggal disitu sampai kasus tersebut selesai, tetapi BP3TKI tidak merespon usul saya".

Menurut SBMI bahwa kendala yang dialami oleh SBMI dalam menangani kasus TKI yang bermasalah, kendalanya ada di pemerintahannya sendiri, pemerintahan tidak merespon usul dari SBMI, Pemerintah kurang adanya respon keberadaan SBMI. Permasalahan yang muncul dari SBMI pada dasarnya adalah dana operasional yang minim, selama ini penggunaan operasional kebanyakan adalah menggunakan dana pribadi dari ketua SBMI dan dana dari hasil usaha yang dilakukan oleh para TKI disisihkan oleh organisasi. Kadang juga dapat dana sumbangan dari SBMI pusat, dana tersebut juga digunakan untuk organisasi dan membangun usaha pelatihan-pelatihan buat para mantan TKI. Pemerintah hanya menganggap bahwa SBMI adalah LSM yang membantu mendampingi TKI yang bermasalah.

Undang-Undang No 21 Tahun 2000 Pasal 30 bahwa Keuangan Serikat Pekerja/ serikat buruh, federasi dan konfederasi serikat pekerja/serikat buruh bersumber dari: a) iuran anggota yang besarnya ditetapkan dalam anggaran dasar atau anggaran rumah tangga. Maksud iuran anggota adalah iuran yang dilakukan tiap bulannya yang dilakukan oleh pengurus dan anggota SBMI supaya organinasi tersebut tetap berjalan; b) hasil usaha yang sah; maksudnya hasil usaha yang dilakukan oleh organisasi SBMI seperti Mem- buka Salon, menjual pakaian, dn hasil dari pelatihan-pelatihan lainnya seperti menjahit, beternak, hasilnya usaha tersebut digunakan untuk membantu menambah iuran organisasi; c) Bantuan anggota atau pihak lain yang tidak mengikat; maksudnya bantuan anggota atau pihak lain yang tidak mengikat berasal dari luar negeri, bantuan dari SBMI pusat atau dari Pemerintah.

Kendala yang dihadapi Serikat Buruh Migran Indonesia dalam memperjuangkan Hak-hak Tenaga Kerja Indonesia yang bermasalah di Kabupaten Kendal sebagai berikut. Pertama, kurangnya dana operasional yang minim dalam membantu menyelesaikan kasus Tenaga Kerja Indonesia atau melakukan pelatihan-pelatihan yang dilakukan oleh Serikat Buruh Migran Indonesia dan anggota. Kedua, kurangnya kerjasama antara pihak PPTKIS dengan pihak Tenaga Kerja Indonesia sehingga menyulitkan penyelesaian permasalahan yang dihadapi melalui proses mediasi. Kendala itu contohnya seperti sulitnya mempertemukan pihak PPTKIS dengan TKI, dan susahnya mencari data PPTKIS yang tidak terdaftar di BP3TKI karena PPTKIS yang illegal. Ketiga, sulitnya dalam memberikan pendidikan kritis terhadap tenaga kerja Indonesia. Keempat, kurangnya respon dari pemerintah dengan adanya SBMI dalam membantu menangani atau menyuarakan Hak TKI yang bermasalah.

\section{f. Upaya Dalam Mengatasi Kendala Serikat Buruh Migran Indonesia Dalam Memperjuangkan Hak-Hak Tenaga Kerja Indonesia Yang Bermasalah}

Dalam mengatasi kendala dalam memberikan perlindungan hukum keselamatan bagi TKI yang bermasalah setelah TKI kembali ke Indonesia dengan empat cara. Pertama, upaya yang dilakukan oleh Serikat Buruh Migran Indonesia dalam mengatasi kendala dana operasional yang minim adalah dengan menarik iuran anggota SBMI perbulan. Kemudian apabila melakukan pelatihan atau kegiatan-kegiatan yang dilakukan Serikat Buruh Migran Indonesia juga mendapatkan sumbangan langsung dari SBMI pusat atau bekerjasama dengan pemerintah.

Kedua, upaya yang dilakukan dalam 
mengatasi kendala kurangnya koordinasi dengan Pihak PPTKIS adalah dengan penyelesaian masalah secara berjenjang sesuai prosedur diawali dengan memberikan pengarahan kepada TKI untuk mengetahui duduk perkara yang sedang dihadapi oleh TKI tersebut. Kemudian dalam proses penyelesaiannya SBMI menyampaikan masalah yang terjadi kepada pihak yang terkait misalnya kepada PPTKIS secara lisan, apabila dengan cara lisan tidak dapat diselesaikan maka SBMI akan menyampaikan kasus tersebut secara tertulis. Biasanya dengan cara tertulis ada PPTKIS yang bisa langsung mendapat tanggapan dan penyelesaian, tetapi apabila dari pihak PPTKIS tidak memberi tanggapan dan penyelesaian dari SBMI mengadu kepada BP3TKI untuk membantu menyelesaikan kasus tersebut.

Ketiga, upaya dalam memberikan pendidikan kritis terhadap tenaga kerja Indonesia SBMI bekerjsama dengan pemerintah dalam melakukan pelatihan-pelatihan yang membangun kesadaran TKI untuk mendapatkan hak-haknya seperti training paralegal hukum, organisasi dan kepemimpinan kepada tenaga kerja Indonesia.

Keempat, upaya yang dilakukan dalam mengatasi kendala kurangnya respon dari Pemerintah dengan adanya keberadaan Organisasi Serikat Buruh Migran Indonesia yaitu dengan menegaskan posisi SBMI dalam penyelesaian permasalahan TKI. Bahwa dalam mendampingi kasus TKI yang bermasalah SBMI bekerjasama dengan pemerintah karena Pemerintah yang mempunyai kewenangan untuk menyelesaikan kasus yang dihadapi oleh TKI Baik diluar negeri maupun didalam negeri. SBMI hanya membantu memberikan informasi supaya tidak terjadi permasalahan-permasalahan berikutnya dan mendampingi TKI menyelesaikan kasusnya apabila TKI tidak berani mengungkapkan kasus yang dialami oleh para TKI.

\section{Simpulan}

Dari hasil penelitian tentang peran serikat buruh migran dalam melindungi hak tenaga kerja indonesia yang bermasalah di kabupaten kendal di atas dapat disimpulkan hal-hal sebagai berikut. Pertama, peran Serikat Buruh Migran Indonesia dalam melindungi hak tenaga kerja Indonesia yang bermasalah belum bisa dikatakan sepenuhnya berhasil. Kedua, kendala yang dihadapi Serikat Buruh Migran Indonesia dalam memperjuangkan hak TKI sendiri adalah kurangnya dana operasional yang minim, kurangnya kerjasama dengan pihak PPTKIS, dan kurangnya respon dari pemerintah dengan adanya keberadaan organisasi serikat buruh migran Indonesia. Ketiga, upaya dalam mengatasi kendala yang dihadapi oleh SBMI dalam melindungi hak TKI, karena kurang nya dana operasional yang minim seharusnya SBMI bekerjasama dengan pemerintah atau SBMI pusat, upaya dalam mengatasi kendala Serikat Buruh Migran Indonesia dalam menangani kasus TKI yang bermasalah yaitu memberikan pengarahan kepada TKI untuk mengetahui kasus apa yang sedang dihadapi oleh TKI dengan pihak PPTKIS, upaya dalam mengatasi kendala Serikat Buruh migrant Indonesia dalam menangani kasus TKI dengan Pemerintah bertanggung jawab untuk meningkatkan upaya perlindungan terhadap TKI, dan upaya dalam memberikan pendidikan dasar terhadap TKI .

\section{DAFTAR PUSTAKA}

Afifudin, dan B.A. Saebani. 2009. Metodologi Penelitian Kualitatif. Bandung: CV. Pustaka Setia

Amiruddin, dan Zaenal Asikin. 2004. Pengantar Metode Penelitian Hukum. Jakarta: PT. Raja Grafindo Persada

Arikunto, S. 2002. Prosedur Penelitian Suatu Pendekatan Praktek. Jakarta: PT. Renika Cipta

Asikin, Zainal, dkk. 1994; Dasar-Dasar Hukum Perburuhan; Jakarta; PT Raja Grafindo Persada

Bambang, R.Joni, Hukum Ketenagakerjaan,Pustaka Setia, Bandung, 2013.

Husni, Lalu. 2003; Pengantar Hukum Ketenagakerjaan Indonesia; Jakarta; PT Raja Grafindo Persada

ILO. 2007; Hak-hak Pekerja Migran; Buku Pedoman; Jakarta

Kartasaputra G. 1992; Hukum Perburuhan di Indonesia berdasarkan Pancasila; Jakarta; Sinar Grafika

Khakim, Abdul. 2003; Pengantar Hukum Ketenagakerjaan Indonesia Berdasarkan Undang-Undang Nomor 13 Tahun 2003, Bandung: PT. Citra Ad- 
itya Bakti;

Moleong, Lexy. 2007. Metodologi Pendidikan Kualitatif. Bandung: Remaja Pustaka

Soepomo Iman. 1976; Pengantar Hukum Perburuhan; Djambatan

Wijayanti Asri. 2012; Sinkronisasi Hukum Perburuhan Terhadap Konvensi ILO; Bandung; Karya Putra Darwati Bandung

\section{Peraturan Perundang-undangan}

Keputusan Menteri Tenaga Kerja Indonesia Republik Indonesia Nomor: Kep-92/MEN/1998 Perlindungan Tenaga Kerja Indonesia Diluar Negeri Dilaksanakan Melalui Asuransi

Keputusan Mentri Tenaga Kerja Dan Transmigrasi Republik Indonesia Nomor: Kep-104A/MEN/2002
Tentang Penempatan Tenaga Kerja Indonesia Ke Luar Negeri

Peraturan Pemerintah Nomor 8 Tahun 1981 Tentang Perlindungan Upah

Undang-Undang Dasar Negara Republik Indonesia Tahun 1945

Undang-Undang Nomor 13 Tahun 2003 Tentang Ketenagakerjaan

Undang-Undang Nomor 2 Tahun 2004 Tentang Penyelesaian Perselisihan Perburuhan

Undang-Undang Nomor 21 Tahun 2000 Tentang Serikat Pekerja/ Serikat Buruh

Undang-Undang Nomor 39 Tahun 2004 Tentang Penempatan dan Perlindungan Tenaga Kerja Indonrsia Di Luar negeri 